\title{
Investigation of Job Satisfaction Levels of Tennis Coaches Who Work in Higher Education Institutions According to Personal Variables
}

\author{
Pero Duygu Dumangöz (Corresponding Author) \\ Department of Physical Education, Istanbul Technical University \\ Ayazaga Campus, 34469, Maslak, Istanbul, Turkey
}

Tel: 90-541-929-9267Ｅ-mail: perophd@gmail.com

Received: April 4, 2021 Accepted: May 1, 2021 Published: May 7, 2021

doi:10.5296/jei.v7i1.18484 URL: https://doi.org/10.5296/jei.v7i1.18484

\begin{abstract}
According to some personal variables, this study examines tennis coaches' job satisfaction levels in higher education institutions. A total of 50 tennis coaches, 16 women (32\%), and 34 men $(68 \%)$ took part in the study. The coaches included in the study are examined in three categories as 26 years and younger (34\%), 27-29 years old (34\%), 30 years old and above $(32 \%)$. Two forms were used as tools for data collection. The first one of these forms is a 6-question form created by the researcher to determine tennis coaches' characteristics. The second one is the Minnesota Job Satisfaction Scale developed by Weiss et al. in 1967 and translated into Turkish by Baycan in 1985. Baycan also conducted the validity and reliability studies of the scale in 1985. The analysis of the data was done in SPSS 26.0 statistics package program. Percentage and frequency distributions were examined in the statistical analysis of the data, independent sample t-test was performed to evaluate the differences between two groups, one-way analysis of variance (ANOVA) was made to determine the difference between more than two groups, and Scheffe test was performed to determine which groups the difference was between. $p$ significance level was accepted as $0.05(\mathrm{p}<0.05)$. As a result, there was no statistically significant difference in job satisfaction levels of tennis coaches according to gender, education level, coaching level, and work experience ( $p>0.05)$, while there was a directly proportional relationship between the age variable and job satisfaction levels $(\mathrm{p}<0.05)$.
\end{abstract}

Keywords: Coach, Tennis, Job satisfaction, Sport management 


\section{Introduction}

The concept of job satisfaction, which first emerged in the $1920 \mathrm{~s}$, began to be fully understood in the 1930-1940s. In recent years, the number of studies to evaluate job satisfaction has increased due to its direct effects on performance and service quality and decreased absenteeism (Chelladurai \& Ogasawara, 2003; Herrera \& Lim, 2003; Pastora, 1993). This research has contributed to establishing systems for periodically measuring the organizational climate and planning improvement actions for the aspects that need to be corrected for the benefits of motivated and increased satisfaction regarding their work and organization.

Business is an essential aspect of human life. The person must support himself/herself and his/her family. In this respect, it is of great importance for the professional to have a business activity that he/she is satisfied with in order to demonstrate a good job performance. In addition to these, there are also points such as remuneration and working conditions that cause employees to affect the profession negatively.

Job satisfaction is now recognized as a vital aspect of employees' mental life, as they spend one-third of the day at work on average.

Recently, discussions about the aspects affecting employees' perception of professional practices have gradually increased. When tennis coaches are explicitly handled, it is known that they often differ from coaches in other branches, such as being employed informally or being informal service providers, and that a small number of them are formally employed. However, the employee's job satisfaction determines the performance; it also affects the ups and downs of performance and determines whether the organization's goals have been achieved (Tentama, Merdiaty, \& Subardjo, 2021).

Modern institutions and organizations use many techniques to increase employees' productivity levels depending on their job satisfaction. These include incentive payments, awards, and gifts, but it is seen that these techniques are often futile, and job satisfaction remains low. Because most of the time, they tend to look at things from a sociological perspective rather than from a psychological perspective. The sociological aspect focuses on society rather than individuals. With these techniques, some critical psychological conditions that prevent job satisfaction are overlooked (Kamrani, Kamrani, \& Kamrani, 2020).

With this research, tennis coaches' job satisfaction levels were determined with an individual perspective rather than a social perspective.

According to Locke (1976), job satisfaction refers to an enjoyable or positive emotional state arising from evaluating an individual's work or work experiences. From early research (Gillet \& Schuwab, 1975; Herzberg, Mausner, \& Snyderman, 1959) to the latest research (Abuhashesh, Al-Dmour, \& Masa'deh, 2019), the relationship between job satisfaction and performance and productivity aims at organizational success, providing a good tool for practitioners to understand and improve the organizational environment.

Sarason (1996) expressed job satisfaction as a person's feelings and attitudes towards their 
job. According to Cowen (1991), it is the combination of psychological, physiological, and environmental conditions that force a person to say they are satisfied with the job; when the person reaches job satisfaction, his/her general welfare and life satisfaction increase.

An organization is a primary requirement to meet the employees' needs to ensure that they are not absent or do not quit. Therefore, it is important to understand employees' preferences in order to meet their needs.

Researchers seem to agree that job satisfaction is multidimensional (Courtney \& Younkyoung, 2017; Robbins \& Judge, 2018; Spector, 1997). The most researched job satisfaction dimensions are job autonomy and job security, supervision, promotion, working conditions, remuneration, colleagues, and social status (Robbins \& Judge, 2018; Theodosiou, Drakou, \& Sdoukos, 2020).

Many studies examine different sports environments' job satisfaction levels (Al-Halig et al., 2014; Lanham et al., 2012; Lee \& Chelladurai, 2017; Kim, 2017). It is seen that the number of studies on the job satisfaction levels of tennis coaches is relatively low. Within the scope of the study's purpose, it was tried to obtain factual information about the job satisfaction levels of tennis coaches working in higher education institutions.

To work as a tennis coach at Turkish universities, it is necessary to have a Level II coaching certificate. Tennis coaches holding a Level I certificate can only work as assistant coaches. In Turkey Tennis Federation's (TTF) Coaching Training Directive, tennis coaches' assigned positions holding a Level 1 Certificate are expressed clearly. According to this, "... They cannot coach alone and must work with a coach holding at least Level 2 certificate." (https://shgm.gsb.gov.tr)

According to the coach training directive of TTF, tennis coaches are classified in (V) levels;

a) Level I, Assistant Coach

b) Level II, Coach

c) Level III, Senior Coach

d) Level IV, Head Coach

e) Level V, Technical Director

\subsection{Theories about Job Satisfaction}

One of the best-known theories about job satisfaction is Herzberg's (1987) "Two Factors", which deals with job satisfaction and job dissatisfaction as two different questions. According to this theory, satisfaction factors (motivators) are related to the content of the job (success, responsibility, recognition, etc.), and dissatisfaction factors (dissatisfaction) are related to the context of the job (working conditions) (relationships with partners, salary, etc.). Potential improvement in job content is expected to increase satisfaction and motivation for high performance. On the other hand, a possible improvement in the work environment (for example, a wage increase) does not increase satisfaction but is expected to prevent 
dissatisfaction.

The "Job Characteristics" theory (Turner \& Lawrence, 1965) is another well-known theory of job satisfaction. Its basic idea is to develop job characteristics that create the right conditions for high professional motivation, satisfaction, and working environment performance. According to this theory, when designing a profession, both the job itself and the employees' characteristics must be considered because different people react differently to the same job. The theory examines job diversity, the required level of knowledge and skills, employee autonomy, the interaction and interaction opportunities in the job's execution, and the employees' responsibility. According to this theory, the more dominant the above elements in a job are, the more satisfied employees will be.

The theory of "Job Satisfaction Aspects" (Smith, Kendall, \& Hulin, 1987) also works as a multidimensional concept that includes interrelated and competitive sub-concepts (obligations, roles, relationships, rewards) that result in satisfaction. Job satisfaction is not expressed in absolute terms but relates to the job's characteristics, the employee's personal circumstances, and the alternatives he or she has. Occupations from the same "field" or the same department can be essential criteria for professional satisfaction, as they act as a benchmark criterion and shape the employee's view of their job.

Coaches play essential roles in the spread and development of sports in society. To do their job in the best way, the coaches' positive feelings about their work, as in every profession, will increase their performance and make them productive. To achieve success in tennis, which is becoming popular day by day in our country, it is crucial that this branch's coaches are satisfied with their work.

The high level of job satisfaction of the coaches affects their self-confidence. Besides, it enables them to raise good athletes by affecting their performance.

This study aimed to determine tennis coaches' job satisfaction levels and the effects of variables such as gender, age, education level, coaching level, and work experience at their current level.

\subsection{Research Question}

Is there a difference in tennis coaches' job satisfaction levels according to personal variables such as gender, age, education level, coaching level, and work experience at the current level?

\subsection{Hypotheses}

H1: There is a significant difference between tennis coaches' job satisfaction levels according to the gender group variable.

H2: There is a significant difference between tennis coaches' job satisfaction levels according to the age group variable.

H3: There is a significant difference between the tennis coaches' job satisfaction levels according to the variable of educational status. 


\section{Macrothink}

H4: There is a significant difference between tennis coaches' job satisfaction levels according to the coaching level variable.

H5: There is a significant difference between job satisfaction levels according to the coaching level's work experience variable.

\section{Method}

\subsection{Research Sample}

The study's universe consisted of tennis coaches providing service in higher education institutions in Turkey (government/private).

There are 57 universities in Istanbul, 13 of which are state universities, and 44 are foundation universities. There are a total of 61 higher education institutions, including four foundation vocational schools (http://www.istanbul.gov.tr). The study sample consisted of 50 tennis coaches who provided service in a higher education institution and were selected by a simple sampling method from Istanbul, Turkey's higher education leader with many universities.

The participating coaches' personal characteristics within the scope of the research are presented in the table below. 
Table 1. Distribution of tennis coaches by personal characteristics

\begin{tabular}{|l|l|l|}
\hline & N & \% \\
\hline Gender & & \\
\hline Female & 16 & 32 \\
\hline Male & 34 & 68 \\
\hline Age & & \\
\hline 26 and below & 17 & 34 \\
\hline 27 - 29 & 17 & 34 \\
\hline 30 and above & 16 & 32 \\
\hline Education Status & & \\
\hline Undergraduate & 17 & 34 \\
\hline Graduate & 33 & 66 \\
\hline Coaching Level & & \\
\hline Level II & 24 & 48 \\
\hline Level III & 26 & 52 \\
\hline Work Experience at the Current Level & & 28 \\
\hline 2-3 years & 14 & 28 \\
\hline 4-5 years & 14 & $\mathbf{1 0 0}$ \\
\hline 6-9 years & $\mathbf{5 0}$ & \\
\hline Ten years and above & & 28 \\
\hline Total & 13 & \\
\hline
\end{tabular}

The gender distribution of tennis coaches participating in the study is $34(68 \%)$ male and 16 $(32 \%)$ women.

When the coaches included in the study are examined in three categories as 26 years and younger, 27-29 years old, 30 years old and above; Coaches aged 26 and younger and those aged $27-29$ have a $34 \%$ share among all coaches with 17 people, while coaches aged 30 and over have a $32 \%$ share with 16 people.

When the distribution of 50 coaches in the study according to their education level is examined, it was observed that 17 (34\%) coaches were at the undergraduate level, and 33 $(66 \%)$ of them were at the graduate level.

When the distribution of the coaching levels of the tennis coaches participating in the study is 
examined, it has been observed that 24 coaches (48\%) are in Level 2, 26 coaches (52\%) are in Level 3.

When the work experience of the coaches in the study is examined in four categories as 2-3 years, 4-5 years, 6-9 years, ten years and more at the coaching level, coaches with a service period of 2-3 years to $4-5$ years have a $28 \%$ share among all coaches with 14 people. Coaches between 6-9 years have a share of $26 \%$ among all coaches with 13 people, while coaches with a service period of 10 years or more have $18 \%$ with nine people.

\subsection{Data Collection}

Filling the scales by the coaches was based on volunteerism. Research data were obtained through face-to-face interviews with the coaches. Since no incorrectly filled scale was found, all of the scale forms filled out by the 50 tennis coaches were used. Filling the scale forms took about 10 minutes. First, the participants were informed about the purpose of the research, and then they were asked to fill in the scale forms.

\subsection{Measurements}

Independent variables of the research are gender, age, education level, coaching level, work experience at the current level, and the dependent variable is job satisfaction.

The data collection tool consists of two sections. The first one is the researcher's Personal Information Form to determine the participants' characteristics, and the second one is the Minnesota Job Satisfaction Scale, which is used to determine the job satisfaction levels of tennis coaches participating in the study.

Personal Information Form: It is a form created by the researcher to determine the gender, age, educational status, coaching level, and work experience at the current level of the tennis coaches.

Minnesota Job Satisfaction Scale was developed in 1967 by Weiss, Dawiss, England, and Lofguist. It was translated into Turkish by Baycan in 1985. Baycan also performed its validity and reliability study. The Cronbach's alpha value of the scale was calculated as 77.

Minnesota Job Satisfaction Scale consists of 20 items. The scale is a 5-point Likert-type scale with each statement having the options "not satisfied at all (1)", "not satisfied (2)", "indecisive (3)", "satisfied (4)", and "very satisfied (5)". The highest score obtained from the scale is 100 , and the lowest score is 20 . High scores are directly proportional to the job satisfaction level of the coach. General satisfaction scores were examined in the research. The general satisfaction score is obtained by dividing the sum of points obtained from the items by 20 .

\subsection{Analysis of Data}

SPSS 26.0 statistics package was used to analyze the data obtained within the scope of the research. The collected data were examined with Kolmogorov Smirnov and distribution graphs in terms of normal distribution in addition to descriptive statistics. In the statistical analysis of the data, percentage and frequency distributions were examined, independent 
sample t-test was used to evaluate the differences between two groups (gender groups, education level, and coaching level), one-way variance analysis (ANOVA) was performed to determine the difference of groups (more-than-two groups) (age groups, work experience at the current coaching level) and Scheffe Test was performed to find out between what groups the difference was. The $\mathrm{p}$ significance level was accepted as $0.05(\mathrm{p}<0.05)$.

\section{Results}

Table 2. Average, standard deviation and t-test results of tennis coaches' job satisfaction scores according to the "gender group" variable

\begin{tabular}{|l|l|l|l|l|l|}
\hline Gender Group & $\mathbf{N}$ & $\overline{\mathbf{x}}$ & SS & $\mathbf{t}$ & $\mathbf{p}$ \\
\hline Female & 16 & 83.37 & 8.51 & \multirow{2}{*}{.232} & \multirow{2}{*}{.817} \\
\cline { 1 - 5 } Male & 34 & 84.52 & 9.63 & & \\
\hline
\end{tabular}

According to Table 2, no significant difference was found between the tennis coaches' job satisfaction scores according to their gender $(\mathrm{p}>0.05)$.

Table 3. ANOVA Results of job satisfaction scores of tennis coaches by "age group" variable

\begin{tabular}{|l|l|l|l|l|l|}
\hline Age Group & N & $\overline{\mathbf{x}}$ & Sd. & F & p \\
\hline 26 and below & 17 & 82.23 & 10.28 & & \\
\cline { 1 - 4 } $27-29$ & 17 & 89.17 & 3.92 & \multirow{2}{*}{4.07} & \multirow{2}{*}{.023} \\
\cline { 1 - 4 } 30 and above & 16 & 81.37 & 10.34 & & \\
\hline
\end{tabular}

When Table 3 is examined, a significant difference was found between the job satisfaction scores of tennis coaches according to the age group variable $[F(2,47)=4.07 ; p<0.05]$. According to the Scheffe test results to determine which age group this difference stems from, it was determined that the 27-29 age group is different from the other groups. Accordingly, it was determined that the job satisfaction scores of the coaches in the 27-29 age group ( $\bar{x}=$ 89.17) were higher than the coaches aged 30 and over $(\overline{\mathrm{x}}=81.37)$ and 26 and under $(\overline{\mathrm{x}}=$ 82.23). 


\section{Macrothink}

Table 4. Average, standard deviation and t-test results of tennis coaches' job satisfaction scores according to the "educational status" variable

\begin{tabular}{|l|l|l|l|l|l|}
\hline Education Status & $\mathbf{N}$ & $\overline{\mathbf{x}}$ & SS & $\mathbf{t}$ & $\mathbf{p}$ \\
\hline High School & 17 & 84.76 & 9.76 & \multirow{2}{*}{.243} & \multirow{2}{*}{.809} \\
\hline Undergraduate and Graduate & 33 & 84.09 & 9.05 & & \\
\hline
\end{tabular}

When Table 4 is examined, no significant difference was found between the tennis coaches' job satisfaction scores according to their educational status $(p>0.05)$.

Table 5. Average, standard deviation and t-test results of tennis coaches' job satisfaction scores according to the "coaching level" variable

\begin{tabular}{|l|l|l|l|l|l|}
\hline Coaching Level & N & $\overline{\mathbf{x}}$ & SS & t & p \\
\cline { 1 - 4 } Level II & 24 & 85.37 & 7.13 & \multirow{2}{*}{.77} & \multirow{2}{*}{.442} \\
\cline { 1 - 5 } Level III & 26 & 83.34 & 10.82 & & \\
\hline
\end{tabular}

When Table 5 is examined, no significant difference was found between tennis coaches' job satisfaction scores according to the level of coaching $(p>0.05)$.

Table 6. ANOVA Results of job satisfaction scores of tennis coaches according to the variable "work experience at the current level"

\begin{tabular}{|l|l|l|l|l|l|}
\hline Work Experience at the Current Level & $\mathbf{N}$ & $\overline{\mathbf{x}}$ & Sd. & F & p \\
\hline 2-3 years & 14 & 81.85 & 10.59 & & \\
\cline { 1 - 4 } 4-5 years & 14 & 86.42 & 5.93 & \multirow{2}{*}{2.31} & \multirow{2}{*}{.088} \\
\cline { 1 - 4 } 6-9 years & 13 & 88.07 & 7.59 & & \\
\cline { 1 - 3 } Ten years and above & 9 & 79.44 & 11.18 & & \\
\hline
\end{tabular}

According to Table 6, no significant difference was found between the job satisfaction scores of the tennis coaches according to the service time at the level they are in $[F(3,46)=2.31$; $\mathrm{p}>0.05]$.

\section{Discussion}

According to the results of this study, which was conducted in order to determine whether 
there is a significant difference between the job satisfaction levels of the tennis coaches working in higher education institutions according to the variables of gender, age, education level, coaching level, and the work experience at the current level; it is seen that tennis coaches generally have a high level of job satisfaction. Besides, while there is no significant difference in the job satisfaction levels of tennis coaches according to gender group, education level, coaching level, and work experience at the current level (Tables 2, 4, 5 and 6), there is a significant difference according to age groups (Table 3).

According to these results, while $\mathrm{H} 1, \mathrm{H} 3, \mathrm{H} 4$, and $\mathrm{H} 5$ were rejected, the $\mathrm{H} 2$ hypothesis was accepted.

According to the results of the study conducted by Andrade, Westover, and Peterson (2019) to investigate whether the gender factor makes a difference in the job satisfaction level of the employees, it has been determined that there is no difference between the job satisfaction of women and men in general. The same result was reached in different research findings (Ehrenberg, 2003; Oshagbemi, 1997; Platsidou \& Diamantopoulou, 2009; Robst et al., 2003; Ssesanga \& Garret, 2005; Westover, 2009; Zoghi, 2003). Many studies have revealed that job satisfaction is higher in women than men across countries (Brush et al., 1987; Clark, 1997; Donohue \& Heywood, 2004; Loscocco \& Bose, 1998; Mason, 1994; Sloane \& Williams, 2000). Besides, in a study conducted by Herrera and Lim (2003) on 138 athletic coaches in the USA, it was found that male coaches had higher job satisfaction levels than female coaches. As it can be seen, there is no consistency between the findings obtained according to the gender variable in the job satisfaction studies in the literature. When Table 2 is examined in our study, the average of the scores that men got from the job satisfaction scale $(\overline{\mathrm{x}}=84.52)$ is higher than the average of women's scores $(\overline{\mathrm{x}}=83.37)$. This situation does not indicate a significant difference.

Questions about how the gender factor affects working people are still current today. Considering gender as a social structure, it may be reasonable to think that there may be changes in women's roles and that these perceptions may differ in different cultures.

The studies in the literature examining the coaches' job satisfaction levels concerning their ages do not seem to match. Drakou et al. (2006) concluded in their study that as the age of coaches of different branches increased in Greece, their job satisfaction levels increased. This result supports the result of our current research. Other studies support the research results when the literature is examined (Herrera \& Lim, 2003; Hickson \& Oshagbemi, 1999; Organ $\&$ Ling, 1995). Some studies do not support research results (Clark, 1997; Miller, 1980). As shown from the results, there is an intricate relationship between age and job satisfaction. According to Herzberg (1987), this relationship is in the form of " $u$ ". Satisfaction is high at the beginning of the work, there is a decrease in job satisfaction in the middle ages, and with the increase of age, there is an increase in job satisfaction. This result can be attributed to the fact that older employees have lower expectations and adapt more to the work environment than younger ones. As the age advances, people tend to adapt more quickly to the job by keeping their expectations more realistic.

In general, studies conducted to date show that as the education levels of the participants 
increase, their job satisfaction levels also increase (Doğan \& Akdere, 2019; Hickson \& Oshagbemi, 1999; Pelit \& Öztürk, 2013; Kış, 2013). The fact that trained tennis coaches approach their profession more scientifically, their educational status provides self-confidence, and their high social status may explain their high job satisfaction. In this study, no significant statistical difference was found between tennis coaches' job satisfaction scores according to their education levels.

It was revealed that the tennis coaches participating in the study had first and 2nd level coaching certificates, and the difference between the job satisfaction levels according to the coaching level variable was not statistically significant. According to this result, it can be said that the increase in the coaching level of tennis coaches does not affect their job satisfaction levels. Ulucan et al. (2011) found no significant relationship in job satisfaction levels according to the type of coaching certificate in their study on professional football clubs' youth coaches. This result is in line with the results of our research.

No significant difference was found in tennis coaches' job satisfaction levels according to the work experience at the level they are in, and studies support this result (Drakou et al., 2006).

As a result, it has been determined that the age group variable has an essential effect on the tennis coaches' job satisfaction levels participating in the study. This situation may be related to increased experience and recognition as a tennis coach with advancing age.

More research should be done, and measures should be taken in line with the recommendations to increase tennis coaches' job satisfaction levels.

This study's results can guide in determining sports managers' and tennis coaches' problems about their work and improving their job attitudes, determining in-service training needs, planning and managing organizational change, and arranging intra-organizational communication dynamics.

This study can be used as a guide and source, if desired, in future studies. It can be applied to compare coaches' job satisfaction levels at different levels or in different branches. It can compare the changes in tennis coaches' job satisfaction levels in the following years. An application can be performed across Turkey.

It can be applied to compare tennis coaches' job satisfaction levels working in private and public institutions.

\section{References}

Abuhashesh, M., Al-Dmour, R., \& Masa'deh, R. (2019). Factors that affect employees' job satisfaction and performance to increase customers' satisfactions. Journal of Human Resources Management Research, 2019, Article ID 354277. https://doi.org/10.5171/2019. 354277

Andrade, M. S., Westover, J. H., \& Peterson, J. (2019). Job satisfaction and gender. Journal of Business Diversity, 19(3), 22-40. https://doi.org/10.33423/jbd.v19i3.2211

Brush, D. H., Moch, M. K., \& Pooyan, A. (1987). Individual demographic differences and 
satisfaction. Journal of Occupational Behaviour, 8(2), 139-155. https://doi.org/10.1002/job. 4030080205

Chelladurai, P., \& Ogasawara, E. (2003). Satisfaction and commitment of American and Japanese collegiate coaches. Journal of Sport Management, 17, 62-73. https://doi.org/ $10.1123 /$ jsm.17.1.62

Clark, A. (1997). Job satisfaction and gender: Why are women so happy at work? Labour Economics, 4(4), 341-372. https://doi.org/10.1016/S0927-5371(97)00010-9

Courtney, C., \& Younkyoung, K. (2017). Intentions to turnover. Leadership and Organizational Development Journal, 38(2), 194-209. https://doi.org/10.1108/LODJ-102015-0227

Cowen, E. L. (1991). In pursuit of wellness. American Psychologist, 46(4), 404-408. https://doi.org/10.1037/0003-066x.46.4.404

Doğan, M., \& Akdere, M. (2019). Research on job satisfaction and burnout levels of taekwondo coaches. Spormetre, 17(2), 154-162. https://doi.org/10.33689/spormetre.452334

Donohue, S., \& Heywood, J. (2004). Job satisfaction, comparison income and gender: Evidence from the NLSY. International Journal of Manpower, 25(2), 211-234. https://doi.org/10.1108/01437720410536007

Drakou, A., Kambitsis, C., Characousou, Y., \& Tzetzis, G. (2006). Exploring satisfaction of sport coaches in Greece. European Sport Management Quarterly, 6(3), 239-252. https://doi.org/10.1080/16184740601094985

Ehrenberg, R. G. (2003). Studying ourselves: the academic labor market. Journal of Labor Economics, 21(2), 267-287. https://doi.org/10.1086/345558

Gillet, B., \& Schwab, D. P. (1975). Convergent and discriminant validities of corresponding Job Discriptive Index and Minnesota Satisfaction Questionnaire scales. Journal of Applied Psychology, 60, 313-317. https://doi.org/10.1037/h0076751

Herrera, R., \& Lim, J. Y. (2013). Job Satisfaction Among Atletic Trainers in NCAA Division Iaa Institutions. Retrieved March 26, 2021, from https://thesportjournal.org/article/ job-satisfaction-among-athletic-trainers-in-ncaa-division-i-aa-institutions

Herzberg, F. (1987). One more time: How do we motivate employees? Harvard Business Review, 87, 109-117.

Herzberg, F., Mausner, B., \& Snyderman, B. (1959). The motivation to work. New York, NY: John Wiley.

Hickson, C., \& Oshagbemi, T. (1999). The effect of age on the satisfaction of academics with teaching and research. International Journal of Social Economics, 26(4), 537-544. https://doi.org/10.1108/03068299910215960

Kamrani, F., Kamrani, N., \& Kamrani, F. (2020). Paranoia and job satisfaction. Journal of 
Social Sciences and Humanities, 59(1), 75-85. https://doi.org/10.46568/jssh.v59i1.326

Kış, A. (2013). Job satisfaction of provincial education inspectors. Inönü University Journal of Education, 14(3), 1-17.

Locke, E. A. (1976). The nature and causes of job satisfaction. In M. D. Dunnette (Ed.), Handbook of industrial and organizational psychology (pp. 1297-1349). Chicago, IL: Rand McNally.

Losocco, K., \& Bose, C. (1998). Gender and job satisfaction in urban China: The early post-Mao period. Social Science Quarterly, 79(1), 91-109.

Mason, S. E. (1994). Gender differences in job satisfaction. The Journal of Social Psychology, 135(2), 143-51. https://doi.org/10.1080/00224545.1995.9711417

Miller, J. (1980). Individual and occupational determinants of job satisfaction. Sociology of Work and Occupations, 7(3), 337-366. https://doi.org/10.1177/073088848000700304

Organ, D. W., \& Lingl, A. (1995). Personality, satisfaction and organizatioal citizenship behavior. Journal of Social Psychology, 135(3), 339-351. https://doi.org/10.1080/00224545. 1995.9713963

Oshagbem1, T. (1997). Job satisfaction profiles of university teachers. Journal of Managerial Psychology, 12(1), 27-39. https://doi.org/10.1108/02683949710164235

Pastore, D. L. (1993). Job satisfaction and female college coaches. Physical Educator, 50, 216-221.

Pelit, E., \& Öztürk, Y. (2010). Job satisfaction levels of hotel business employees: A research on rural and city hotel employees. Journal of Business Studies, 2(1), 43-72.

Platsidou, M., \& Diamantopoulou, G. (2009). Job satisfaction of Greek University professors: Is it affected by demographic factors, academic rank and problems of higher education? In G. K. Zarifis (Eds.), Educating the Adult Educator: Quality Provision and Assessment in Europe, Conference Proceedings (pp. 535-545). Thessaloniki: Grafima Publications.

Robbins, S. P., \& Judge, T. A. (2018). Essential of organizational behavior (14th ed.). London: Pearson Eds.

Robst, J., VanGilder, J., \& Polachek, S. (2003). Perceptions of female faculty treatment in higher education: Which institutions treat women more fairly? Economics of Education Review, 22(1), 59-67. https://doi.org/10.1016/S0272-7757(01)00056-5

Sarason, S. (1996). Barometers of Change: Individual, Educational, and Social Transformation. Choice Reviews Online, 34(3), 34-1516. https://doi.org/10.5860/choice. $34-1516$

Sloane, P. J., \& Williams, H. (2000). Job satisfaction, comparison earnings and gender. Labour, 14(3), 473-502. https://doi.org/10.1111/1467-9914.00142

Smith, P. C., Kendall, L. M., \& Hulin, C. C. (1987). The measurement of satisfaction in work 
and retirement. Chicago, IL: Rand McNally.

Spector, P. E. (1997). Job satisfaction-Application, assessment, couses, and consequences. Thousand Oaks, California: SAGE Publications. https://doi.org/10.4135/9781452231549

Ssesanga, K., \& Garrett, R. M. (2005). Job satisfaction of university academics: Perspectives from Uganda. Higher Education, 50(1), 33-56. https://doi.org/10.1007/s10734-004-6346-0

Tentama, F., Merdiaty, N., \& Subardjo (2021). The job satisfaction of university teachers. Journal of Education and Learning, 15(1), 48-54. https://doi.org/10.11591/edulearn.v15i1. 17054

Theodosiou, A., Drakou, A., \& Sdoukos, T. (2020). Job satisfaction and job commitment of Greek tennis, table-tennis and badminton coaches. International Journal of Racket Sports Science, 2(2), 47-58. https://doi.org/10.30827/Digibug.65363

Turkish Tennis Federation. (2021). Tennis Coach Training Instruction. Retrieved March 5, 2021, from https://shgm.gsb.gov.tr/Public/images/SGM/Federasyon/Tenis\%20Antrenoru\%20 Egitim\%20Ta.pdf

Turner, A. N., \& Lawrence, P. R. (1965). Industrial jobs and the worker. Boston: Harvard Graduate School of Business Administration.

Ulucan, H., Erol, A. E., Bektaş, F., \& Yılmaz, İ. (2011). Investigation of the job satisfaction levels of the trainers working at the infrastructures of professional football clubs in Turkey. Selcuk University Journal of Physical Education and Sports Science, 13(2), 226-232.

University City Istanbul. (2021). T.R. Istanbul Governorship Official Website. Retrieved March 26, 2021, from http://www.istanbul.gov.tr/universite-sehri-istanbul

Westover, J. H. (2009). A cross-national look at the changing nature of gender differences in perceived job satisfaction. International Journal of Global Business and Economics, 2(1), 62-67.

Zoghi, C. (2003). Why have public university professors done so badly? Economics of Education Review, 22(1), 45-57. https://doi.org/10.1016/S0272-7757(01)00058-9

\section{Copyright Disclaimer}

Copyright for this article is retained by the author(s), with first publication rights granted to the journal.

This is an open-access article distributed under the terms and conditions of the Creative Commons Attribution license (http://creativecommons.org/licenses/by/3.0/). 